\title{
Előszó Kuszmann János életpályáját bemutató írásához
}

Amikor, immár 18. éve felkértek a Magyar Kémiai Folyóirat föszerkesztőjének, bár a lap évszázados hagyománnyal büszkélkedhetett, jövője rendkívül bizonytalan volt, sőt a megszűnés közvetlen veszélye fenyegette. A felkérés elvállalása azt is jelentette, hogy főszerkesztőként az első és legföbb feladatom a folyóirat megmentése, életben tartása lesz. A tulajdonos, a Magyar Kémikusok Egyesülete vezetősége és a társfenntartó, a Magyar Tudományos Akadémia Kémiai Tudományok Osztályának tagjai, néhány kivétellel, szinte egyöntetüen a megszünés pártján álltak. Nehezen vitatható érveik lényege az volt, hogy az értékes új hazai kutatási eredményeket nem szabad a magyar nyelvü közlés okán a nemzetközi tudományos közélet elől elrejteni, a kevésbé jelentősekre pedig kár a papírt pazarolni. Ezért a lap megmentése csak úgy volt elképzelhető, ha közzétételre érdemes, s zömmel nem a hazai kutatások aktuális eredményeit tartalmazó publikációkkal töltjük meg.

Egyik közleménytípus, ami a fenti feltételeknek megfelel, azon kiemelkedő teljesítményt elért magyar kémikusok pályafutásának bemutatása, megörökítése lehetett, akik, bár rászolgáltak, mégsem lettek a Magyar Tudományos Akadémia tagjai. Míg az akadémikusok szakmai pályafutásáról bőséges dokumentáció marad fenn, akiket nem választottak MTA-taggá, azokról csak esetlegesen maradtak/ maradnak fenn tudományos eredményeiket szakszerüen és tárgyilagosan bemutató anyagok. E megfontolás jegyében indult útjára a folyóirat egyik új rovata, amelyben nem akadémikus kémikus szaktekintélyek életet és munkásságát áttekintő írások láthatnak napvilágot. Első sorban már nem élö kiválóságokról jelentek meg életrajzok, de még életben lévő, sőt egyes esetekben még aktív kémikusok közül is felkértünk néhány megkérdőjelezhetetlenül kimagasló életmüvet felmutató kortárs kollégánkat, hogy mint legilletékesebbek, állítsanak össze magukról egy szakmai munkásságukat és életük legfontosabb momentumait összefoglaló írást.

Ezzel nem adtunk könnyü feladatot a kiválasztottaknak, mert emberpróbáló valakinek önmagáról tárgyilagosan, elfogulatlanul, érzelmektől mentesen, s a természetes szerénységet leküzdve, ugyanakkor túlzott önelégültségtől mentesen beszámolni életének eseményeiről, érdemeiről és szakmai teljesítményeiröl.
Kuszmann János professzor, a kémiai tudományok doktora, az egykori Gyógyszerkutató Intézet tudományos fötanácsosa és ,az intézet örökös tagja” is meghívást kapott, hogy a Magyar Kémiai Folyóiratnak a jelenkor kémikus kiválóságait bemutató rovatában írjon beszámolót kémikusi életpályájáról.

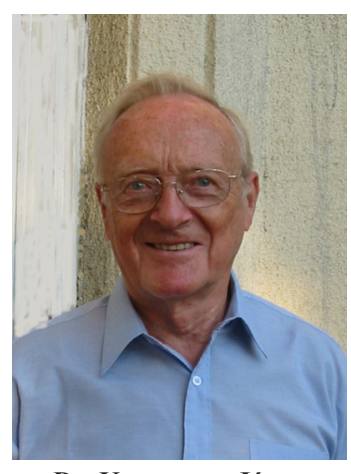

Dr. Kuszmann János

Kuszmann János a Gyógyszerkutató Intézetnek megszünéséig emblematikus személyisége, bizonyos értelemben „arca” volt! Amellett, hogy kiemelkedő tudományos kutatási eredményeivel tekintélyt szerzett az Intézetnek, egyfajta "külügyminiszteri”, „menedzseri” és minőségbiztosítási szerepet töltött be. Kimagasló nyelvtudása révén a külföldi partnerekkel tárgyalásokon, külföldi vendégek fogadásakor impresszíven képviselte intézetét, mintegy intézeti idegenvezetőként funkcionált, idegen nyelvű anyagok magyarra fordításába, illetve magyar nyelvü anyagok idegen nyelvekre való átültetésében fordítóként, vagy a mások által lefordított szövegek ellenőrzésében, javításában, az idegen nyelvű levelezéseknél nemcsak az intézeti ügyekben vállalt szerepet, de kollégáit, munkatársait is önzetlenül segítette e területeken. Kitűnő kritikai érzéke predesztinálta kollégái és munkatársai szakmai írásainak ellenőrzésére, javítására. Nemcsak a munkatársai publikációinak ellenőrzésében, azok fogyatékosságainak feltárásában volt mások segítségére, de az intézetből kikerülö értekezések szerkesztésében, a szakmai hibák, pontatlanságok észrevételében és eliminálásában, a fogalmazás csiszolásában is közremüködött. Kritikusi feladatokat nemcsak az intézeten belül, de folyóiratok lektoraként, az Akadémián kandidátusi, nagydoktori értekezések hivatalos bírálójaként is általános elismerést és tekintélyt kivívó szakértelemmel, „,sasszemekkel” látta el. 


\title{
50 év a gyógyszerkutatás büvöletében
}

\author{
KUSZMANN János*
}

\begin{abstract}
A Szepességben, a Magas Tátra alján fekvő Késmárkon születtem 1933-ban. Ez akkor természetesen már Szlovákiához tartozott, de a mi családunk megtartotta német nemzetiségét, így én végig német iskolákba jártam. Igaz, a nyári szüneteket többnyire Szegeden, nagybátyámnál, Bruckner Győzőnél töltöttem, de ott is legszívesebben az egyetem németül tudó üvegtechnikusánál, Schlott bácsinál időztem, ahol nemcsak az ujjaimat sikerült többször megégetnem, de megtanultam az üvegfúvás alapjait is. Alighanem emiatt is határoztam el, hogy majd a vegyészi pályára lépek.
\end{abstract}

A háború után a szlovák kormány természetesen beszüntette a német iskolák müködését, így én 1946-ban egy félévig csak a szlovák polgári iskolában folytathattam tanulmányaimat. Miután ekkor sor került a német és magyar kisebbségek deportálására, ez elől illegálisan Magyarországra szöktünk rokonainkhoz, ahol először Cegléden, majd Miskolcon immár magyar nyelven folytattam tanulmányaimat. Mivel akkor még nem tudtam magyarul minden leckét memoriterként kellett bemagolnom! Végül 1952-ben Miskolcon a Földes Ferenc Gimnáziumban érettségiztem már kitünő eredménnyel, majd ugyanabban az évben felvettek a Budapesti Müszaki Egyetem Vegyészmérnöki Karára. Azért nem mentem a TTK-ra, mert nagybátyám akkor már ott volt a Szerveskémiai Tanszék vezetője, és nem akartam, hogy emiatt ott ebből bármi előnyöm - vagy hátrányom származzon.

Egyetemi tanulmányaimat 1957-ben fejeztem be. A Budapesti Gyógyszeripari Kutatóintézetben ${ }^{1}$ helyezkedtem el, ahol az intézet Igazgatója, Vargha László akadémikus laborjában, az ö közvetlen munkatársaként kezdtem meg kutatói pályafutásomat.

Itt bekapcsolódtam azokba a kutatásokba, amelyek az általa néhány éve szintetizált, rákellenes hatású, a bifunkciós biológiai alkilezőszerek csoportjába tartozó, leukémia elleni gyógyszerként bevált Degranol (1) rokon vegyületeinek a szintézisét tűzték ki célomul, mivel akkor már ismert volt az Angliában kifejlesztett Myleran (1,4-di-O-mezil-butándiol) nevü citosztatikus hatású vegyület, amelynek hátránya azonban annak vízben való oldhatatlansága volt. Célszerünek látszott a Degranol analógiájára egy olyan potenciálisan rákellenes hatású cukoralkohol származéknak az elóállitása, amelyiken a biológiailag aktív meziloxi csoportok a molekula lánc-végein foglalnak helyet. Így kertült sor az 1,6-di-O-mezil-D-mannit (2) szintézisére, amelyet két úton is sikerült elöállítanom. ${ }^{2,3}$

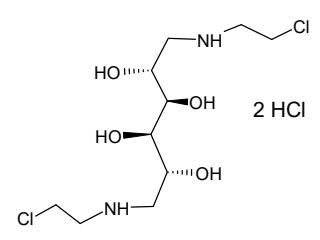

1 Degranol

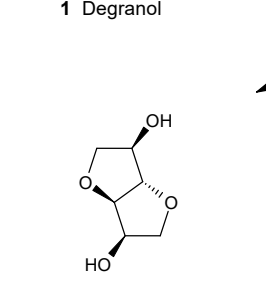

3 1,4:3,6-Dianhidro-D-mannit

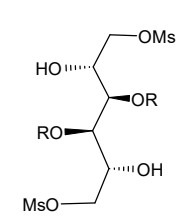

$2 \mathrm{R}=\mathrm{H}$ Mannitol-Myleran $4 \mathrm{R}=\mathrm{Me} \mathrm{GYKI}-17230$

$\checkmark$

5 1,2:5,6-Dianhidro-3,4-di-O-metil-D-mannit

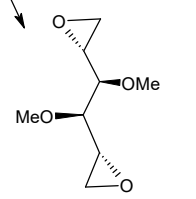

A vegyület a klinikai kipróbálás során rendkívül jó rákellenes hatást mutatott és a Degranollal ellentétben nemcsak a vérképző rendszer rosszindulatú elváltozásit (Leukémia), hanem egyes tumorok kifejlődését is meggátolta. Ezek alapján Mannitol-Myleran néven került volna forgalomba, de a klinikai vizsgálatok során az is kiderült, hogy a vegyület annyira aktív, hogy a szobahőmérsékleten való tároláskor lassan egy önalkilezés során, metánszulfonsav kilépése közben a megfelelő hatástalan dianhidro vegyületté (3) bomlik, így végül gyógyszerként nem kerülhetett kereskedelmi forgalomba. Majdnem 20 évvel később (1979-ben), az 1,6-tioanhidro-hexitek elő́llítása során intermedierként elöállítottam az 1,6-di-O-mezil-3,4-di-O-metil-D-mannitot (4), amelyik szobahömérsékleten stabilnak bizonyult és szintén kiváló citosztatikus hatással rendelkezett. ${ }^{4}$

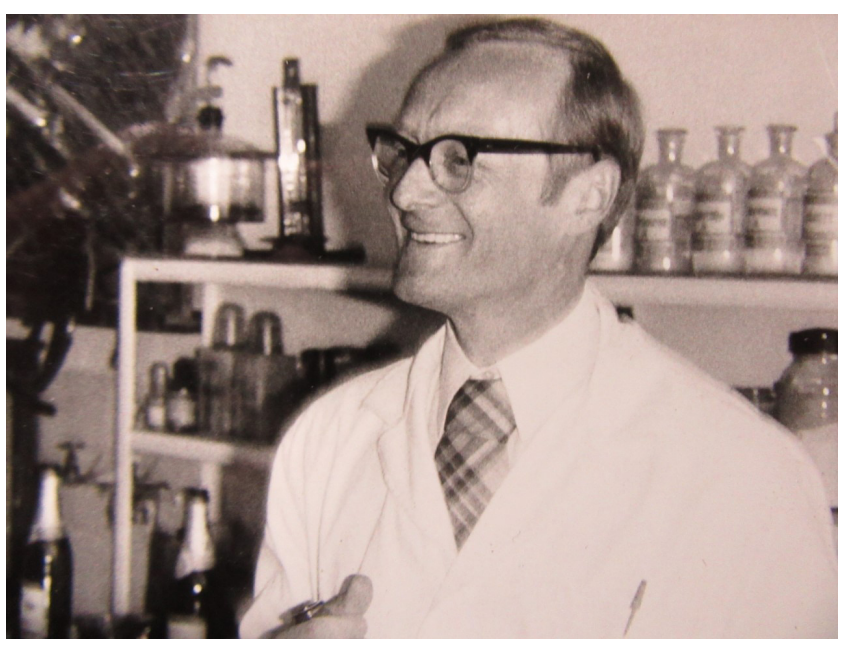

Dr. Kuszmann János munka közben, a laborban 
A vegyület biológiai vizsgálatánál kiderült, hogy az egyik metabolitja a megfelelő 1,2:5,6-dianhidro származék (5), amelyik a terminális epoxi csoportok révén a kiindulási vegyülettel azonos aktivitást mutatott. Mivel ekkor még érvényben volt a Gyógyszeripari Tröszt azon rendelkezése, mely konkrét gyárakra ,profilírozta” az egyes biológiai aktivitással rendelkező potenciális gyógyszerjelöltek fejlesztését, ez a vegyület a Chinoin gyógyszergyár „portfóliójába” került (GYKI-17230 néven), ahol a további klinikai vizsgálatokat koordinálták volna. Sajnos a Chinoinban, amelyik a Degranol előállítása során maga is érdekelt lett az új citosztatikus hatású vegyületek előállításában, egy hasonló biológiai spektrummal rendelkező anyag előállításán dolgoztak, így a mi vegyületünket az övékével párhuzamosan kívánták az Onkológiai Intézetben a klinikai vizsgálatoknak alávetni. Kiderült azonban, hogy az Onkológiai Intézet kapacitása egyszerre csak egy vegyület vizsgálatára elegendő, így a Chinoin természetesen a saját vegyületének biztosított elsőbbséget. Ezekben a vizsgálatokban azonban az ő vegyületük esetén nem igazolták a várt citosztatikus aktivitást! Ezek után viszont a gyár úgy döntött, hogy a biológiai alkilezőszerek piaca már úgyis telítődött, így a mi vegyületünk további fejlesztéséről lemondott!

Ekkor fogalmazódott meg bennem a következő gondolat. Egy gyógyszerkutató életében két kellemetlen esemény következhet be: az egyik, hogy munkája során nem fedez fel új, biológiailag aktív molekulát, a másik pedig az, ha felfedez egyet. Utóbbi esetben ugyanis rengeteg energiát kell ahhoz befektetnie, hogy a potenciális gyógyszerjelöltből valóban gyógyszer váljon. Hiszen az első sikeres laborszintézist követően optimalizálni kell a reakció-körülményeket, majd iparilag nagyítható eljárást kell kidolgoznia. Ehhez el kell készítenie az összes ehhez szükséges dokumentációt, beleértve az analitikai elemzések elöírásait, meg persze a megfelelő szabadalmi bejelentést, amelyhez, mivel ebben rendszerint célszerü az oltalmi kört az összes analóg vagy rokon vegyületre is kiterjeszteni, ezért ezek előállítását is meg kell oldania! Ez hatalmas munka, mely sokszor 1-2 évig is elhúzódhat - és végül nem biztosítja a sikerélményt, hiszen a vegyület sorsa rengeteg, rajta kívülálló tényezőn múlik, és az esetek többségében a végén mégsem lesz belőle gyógyszer! Az olvasóra bízom annak eldöntését, hogy melyik variáció jelent nagyobb csalódást a kutatónak!

Ezek a kudarcok azonban nem vették el kedvemet a gyógyszerkutatástól, de ha lehetett, a különbözö biológiai hatások céljából előállított új vegyületek esetében mindig igyekeztem hasznosítani a szénhidrátkémiai tudásomat is, amelyre az előbb említett témák során tettem szert. Ebben aztán Vargha professzor is támogatott, hiszen alapjában véve ő

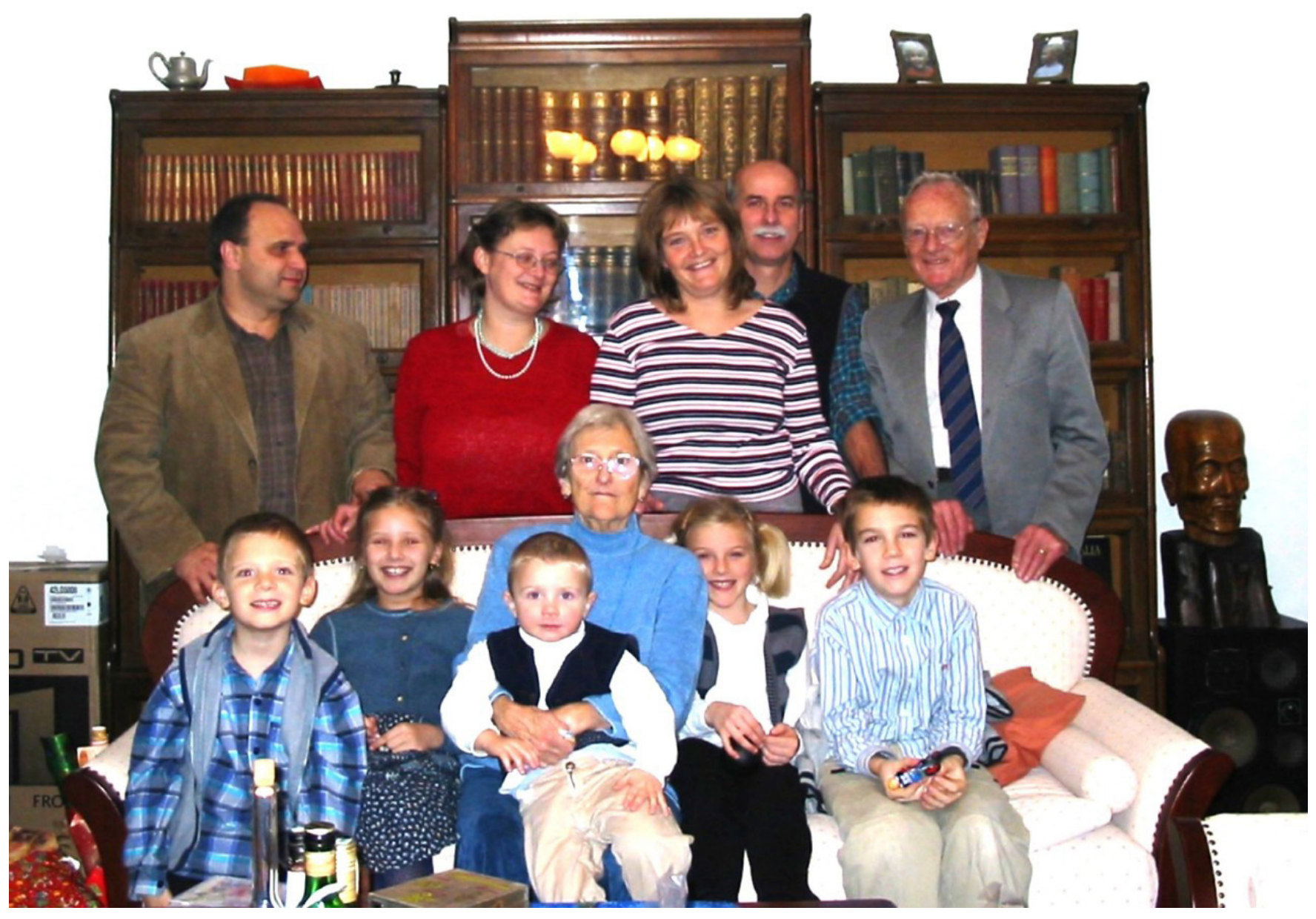

Dr. Kuszmann János családja körében karácsonykor az öt unokával 
is többek között a szénhidrátkémiában érte el kiemelkedő tudományos eredményeit. A szénhidrátok azért is lettek „kedvenc” vegyületeim, mert aszimmetrikus molekulák révén sok sztereokémiai probléma is felmerült származékaik szintézise során. Márpedig én még középiskolás koromban tanultam ábrázoló geometriát, és mivel jó a térlátásom, ez egyik kedvenc tantárgyam lett. Ez aztán ugyancsak hasznosnak bizonyult a szénhidrátokkal való munkám során, hiszen a reakciók lefutását erősen befolyásolják a sztérikus faktorok, amelyek a reakciómechanizmusokban is fontos szerepet játszanak. Azt szoktam mondani, hogy ha egy tervezett reakció a várakozásnak megfelelően megy végbe, ez ugyan sikerélmény, de ha egy nem várt eredmény születik, akkor válik a kutatás izgalmassá! Mert az első kérdés: mi az új vegyület (a szerkezetfelderítés problémája), a második: miért ez keletkezett a várt vegyület helyett (a reakciómechanizmus kiderítése) és végül a harmadik: hogy tudom a természetet arra kényszeríteni, hogy a várt terméket kapjam meg! Ha ez sikerül, úgy a természet felett aratott „győzelem" egy sokkal nagyobb sikerélmény!

A Gyógyszerkutató Intézetben eltöltött idő alatt a biológiailag aktív cukorszármazékok kutatása során az előbb említetteken kívül a következő vegyülettípusok szintézisével értem el gyógyszerkémiailag értékelhető eredményeket:
A rákellenes szerek körében gyakran alkalmazott N-mustár származék az Endoxan, amelyikben a nitrogén bázicitását gyürüs foszforsavamiddá való átalakításával csökkentették. Ilyen típusú, cukor alapú gyürüs foszforsavamidok sorát állítottuk elö, és bebizonyítottuk, hogy a vegyületek citosztatikus aktivitása a foszfor atom konfigurációjától függ. ${ }^{5}$

A pirimidin nukleozidok körében sikerült a rákellenes hatású antimetabolitként ismert ciklocitidinre (2,2'-anhidro-arabofuranozido-citozin) egy új, szabadalmilag védhető szintézis utat kidolgoznunk. E vegyület és analógjainak N-metilezési reakcióinak a tanulmányozásával új típusú mono- és dianhidro-nukleozidokat állítottunk elö. ${ }^{6}$

Az új dianhidro-cukoralkohol származékok vizsgálata számos elméleti érdekességű probléma megoldásán kívül egy altató hatású vegyülethez, az 1,4:3,6-dianhidro2,5-diazido-L-mannit szintéziséhez vezetett, ${ }^{7}$ mely hatásmódját tekintve különbözött az eddig ismert összes altatótól.

A tioanhidro cukoralkoholok témakörében végzett kutatómunkám során egy új, gyomorsav szekréciót csökkentő anyag szintézisét oldottam meg, amely rendkívül erős ulcus-gátló hatással rendelkezett. ${ }^{8}$

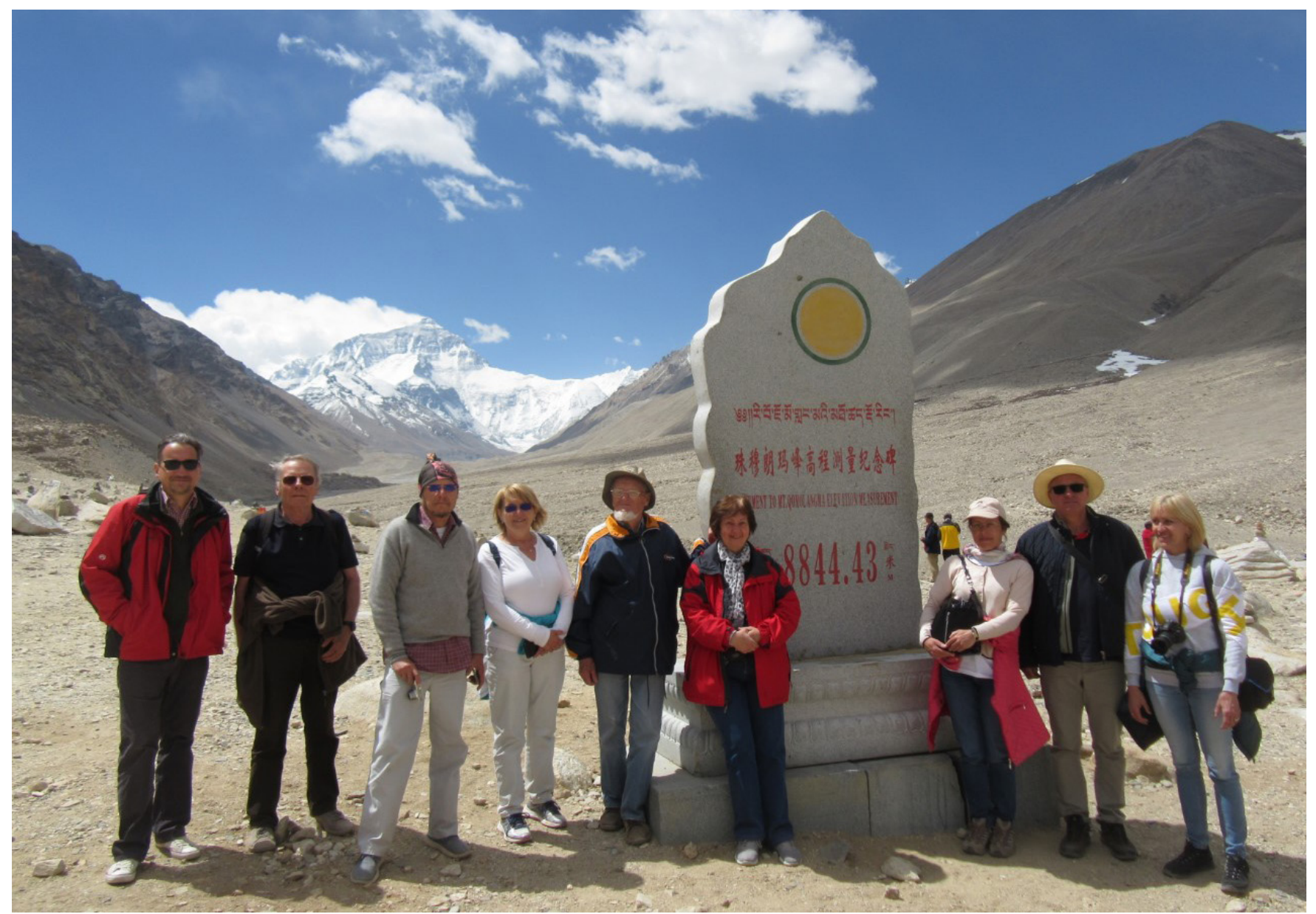

Dr. Kuszmann János 85 évesen Tibetben, a Mt Everest alaptáboránál 
A glükózból kiinduló aminocukor-szintézisek témakörben dolgoztuk ki a citosztatikus hatású adriamicin cukorszármazékának, a Daunózaminnak D-glükózból kiinduló elöállítását, mely egyben furanozidjainak és analógjainak a szintézisét is lehetővé teszi. ${ }^{9}$ De a fermentációval előállítható Daunomicinnek a nála kedvezőbb hatásó Adriamicinné való átalakításárára is kidolgoztunk egy módszert.

A tiocukrok tiopiranozidjainak a szintézise során számos olyan származékot állítottunk elő, amelyek orális antitrombotikus hatással rendelkeztek. Ebből a témakörből három szabadalom és 15 publikáció készült. ${ }^{10}$ A szabadalmakat megvette a Richter Gedeon Gyógyszergyár, de a téma később „,témaszükítés” áldozata lett és így végül egyik vegyületből sem lett gyógyszer.

A szénhidrát-kémiai kutatásokon kívül természetesen más témákkal is foglalkoznom kellett, így többek között fluorozott szteroidokkal, ${ }^{11}$ valamint az intézetben folyó ipari kutatási témák kapcsán véralvadásgátló, koronária tágító, széles spektrumú gyulladásgátló, immunszuppressziv és fájdalomcsillapító hatású kumarin-, benzofurán-, benzimidazol- és purin-származékokra dolgoztam ki laboratóriumi elöiratokat.

Az intézetben egyébként bejártam a szokásos „szamárlétrát", mert mint segédmunkatárs vettek fel Vargha professzor mellé, majd tudományos munkatárs (1960), aztán főmunkatárs (1967), tudományos tanácsadó (1973), tudományos osztályvezető (1977), majd műszaki fõtanácsos és a Szénhidrátkémiai Csoport vezetője lettem egészen 2008-ig, amikor az intézet akkori tulajdonosa a TEVA Gyógyszergyár azt fel nem számolta.

1960-ban benyújtottam a Budapesti Müszaki Egyetemre „2-Deoxi-2-klór-pentózok elóállítása” címü doktori dolgozatomat, amelynek alapján 1961-ben müszaki doktorrá avattak.

1963-ban a „2’-Dezoxi-2’-klór adenozidok szintézise” címü kandidátusi dolgozatot adtam be a TMB-hez, majd 1971ben a „Vizsgálatok az anhidro- és tioanhidro hexitek körében" címü doktori értekezésemet, és ezek alapján nyertem el a Kémiai Tudományok Kandidátusa, ill. a Kémiai Tudományok Doktora címet.

Amikor 1971-ben az MTA Szerveskémiai Osztályán belül megalakultak a különböző munkabizottságok, a Szénhidrátkémiai Munkabizottság elnöki tisztségét Vargha professzor úrnak ajánlották fel. Mivel ezt, mint a Gyógyszerkutató Intézet Igazgatója már nem tudta elvállalni, végül Bognár Rezső akadémikus lett a munkabizottság elnöke, aki akkor már a Debreceni Kossuth Lajos Tudományegyetem Szerves Kémiai Intézetének professzora volt. Ö azzal a feltétellel fogadta el ezt a kinevezést, ha én elvállalom a titkári funkciót. Ezzel természetesen rám hárult az ezzel járó összes adminisztratív tevékenység, igy az évente esedékes munkabizottsági ülések megszervezé- se, továbbá így lettem 1981-ben a Budapesten megtartott KGST szénhidrátkémiai értekezletnek, valamint 1983ban a, $2^{\text {nd }}$ Eropean Symposium on Carbohydrates and Glycoconjugates" című nemzetközi kongresszusnak is a szervezője. Titkári tisztségemet 22 évig, 1993-ig láttam el.

1966-ban a WHO ösztöndíjával 9 hónapot töltöttem Londonban, a „Chester Beatty Research Institute” nevü rákkutató intézetben, ahol citosztatikus hatású nukleozid származékok szintézisével foglalkoztam. ${ }^{12}$

1988-ban egy évet Andrea Vasella professzor úr meghívására a Zürichi Egyetem Szerves Kémiai Tanszéken folytattam kutatómunkát, melynek során sikeresen megoldottam néhány $\mathrm{N}$-acetilneuraminsav származéknak a szintézisét. ${ }^{13}$

Az MTA több munkabizottságának is tagja voltam (Elméleti Sztereokémiai Munkabizottság 1971-től, Szerves Kémiai Bizottság 1996-tól) és Magyarországot képviseltem az Európai Szénhidrátkémiai Szervezetben (ECO) 1985 és 2005 között. 1991-től több évig mind a BME mind a Debreceni KLTE meghívott előadója voltam, ahol Szénhidrátkémiát és Természetes Szerves Anyagok kémiáját adtam elő fakultatív tantárgyként. Utóbbi egyetem 1994-ben kinevezett címzetes egyetemi tanárnak. 2001 és 2004 között az MTA Köztestületi tagjainak képviselője voltam. A Magyar Ösztöndíjbizottság Természettudományi Szakmai Kollégiumának pedig 2001 és 2014 között voltam tagja. 128 tudományos közlemény, 24 szabadalom és három könyvfejezet ${ }^{14-16}$ szerzője, illetve társzerzője voltam. Természetesen nagyon sok bel- és külföldi kongresszuson vettem részt, ahol többnyire előadásokat is tartottam.

Munkám elismeréseképpen 1975-ben a NIM kiváló dolgozója lettem, 1982-ben a Munkaérdemérem bronz fokozatával tüntettek ki, 1984-ben az MTA-tól a Zemplén Géza díjat, 1991-ben a Bruckner díjat ítélték nekem, és 2014-ben az Eötvös József koszorúval tüntettek ki.

Ami a privát életemet illeti, 1958-ban feleségül vettem korábbi évfolyamtársnőmet Borbély Annát, aki egészen nyugdíjazásáig a BME különböző tanszékein folytatott oktatói tevékenységet. Két lányunk született, majd idővel a családunk kibővült 5 unokával, de közülük senki sem akart már vegyész lenni.

Mint a Tátra szülötte természetesen már gyerekfejjel megtanultam síelni, és ezt a sportot Magyarországra való áttelepülésünk után is folytattam, természetesen többnyire a környező országok síterepein egészen 80 éves koromig. Nejemmel egyébként lelkes turisták voltunk és sok magashegyi túrát tettünk a Tátrában, az Alpokban, a Fogarasi Havasokban, sőt még a Kaukázusba is eljutottunk, ahol a szuhumi hadiutat jártuk végig. Később inkább társasutazások keretében fedeztük fel a világot és Európa, Ázsia, Amerika és Afrika sok országában jártunk. Feleségem 2009-ben rákban halt meg. 


\section{Irodalomjegyzék}

1. 1. A.Simay: A Gyószerkutató Intézet története és föbb eredményei. Acta Pharmac. Hung. 71 (2001) 7-12

2. L. Vargha and J. Kuszmann: 1,6-Dimethanesulfonyl-Dmannit, eine neue tumoraffine Substanz. Die

Naturwissenschaften 46 (1959) 84 https://doi.org/10.1007/BF00599123

3. L. Vargha, Ö. Fehér, T. Horváth, L. Toldy und J. Kuszmann: Über die Synthese neuer Zuckerderivate mit potenzieller cytostartischer Wirksamkeit. Acta Chim. Hung., 25 (1960) 361-368

4. J. Kuszmann: 3,4-Di-O-alkylhexitol derivatives containing biological alkylating groups at C-1 and C-6. Carbohydr. Res. 71 (1979) 123-134

https://doi.org/10.1016/S0008-6215(00)86066-8

5. Kuszmann J. Rákellenes hatású anyagok kutatása a Gyógyszerkutató Intézetben. Acta Pharm. Hung. 71 (2001) 57-66.

6. M. Márton-Merész, J. Kuszmann and I. Pelczer: Synthesis and reaction of 2',3'-anhydro-1-D-ribofuranosyl-uracil derivatives.Tetrahedron 39 (1983) 275-284. https://doi.org/10.1016/S0040-4020(01)91819-8

7. J. Kuszmann and G. Medgyes: Synthesis and biological activity of 1,4:3,6-dianhydro-2,5-diazido-2,5-dideoxyhexitols. Carbohydr. Res. 85 (1980) 259-269. https://doi.org/10.1016/S0008-6215(00)84675-3

8. J. Kuszmann, P. Sohár and Gy. Horváth: Acetalation of 1,6-anhydro-1(6)-thio-D-glucitol. Carbohydr. Res. 50 (1976) 45-52 https://doi.org/10.1016/S0008-6215(00)84081-1
9. G. Medgyes and J. Kuszmann: Synthesis of 3-amino-2,3,6-trideoxy L- lyxo-hexose (daunosamine) hydrichloride from D-glucose. Carbohydr Res. 96 (1981) 306-311. https://doi.org/10.1016/S0008-6215(00)80395-X

10. G. Szabó, É. Bozó, É.Barabás, R. Kedves, K.Csomor and J. Kuszmann: Thioglycoside antithrombotic agents. Drugs of the Future, 24 (1999) 1241-1248. https://doi.org/10.1358/dof.1999.024.11.560611

11. Á. Néder, I. Pelczer, Zs. Méhesfalvi and J. Kuszmann: Fluorinated steroids . Acta Chim. Hung. 109 (3) 275-285 (1982)

12. M. Jarman, J. Kuszmann and J.A-Stock: Aminoacyl Nucleosides derived from the tumour inhibitor, 1-aminocyclopentane-carboxylic acid. Biochem. Pharm. 18 (1969) 2473-2484. https://doi.org/10.1016/0006-2952(69)90363-3

13. L. Czollner, J. Kuszmann and A. Vasella: Synthesis of Pyrrolidine Analogs of N-Acetylneuraminic Acid as Potential Sialidase inhibitors. Helv. Chim. Acta 73 (1990) 1338-1358. https://doi.org/10.1002/hlca.19900730522

14. Kuszmann János: Citoszatikus hatású vegyületek kémiája. Akadémiai Kiadó Budapest A kémia Újabb eredményei 17 (1974) 7-132.

15. Kuszmann János: Rákellenes szerek. Tankönyvkiadó, Gyógyszerkémia II (1992) 1112-1159.

16. J. Kuszmann: Introduction to Carbohydrates. The Organic Chemistry of Sugars (2006) 25-52 Ed. Daniel E. Levy, Péter Fügedi, CRC Press, USA. https://doi.org/10.1201/9781420027952.ch2

\section{Summary}

I was born in 1933 in Kesmark, at the foot of the High-Tatras, which at that time was the northern border of Hungary and was a German speaking region. After the first World War this part of Hungary became a part of Czechoslovakia, but as the government guaranteed some autonomy to the non-Slovakian minorities, consequently I was educated in German Schools. However, after the second World War the newly establishes Slovak government closed all non-Slovak schools, therefore I had to continue my studies at a Slovak school, but as the policy became more hostile towards the non Slovak minorities, we left the country and fled to Hungary where some of our relatives lived. There I had to continue my studies in Hungarian, which I never learned in spite of the fact, that as a child I often spent my holidays In Szeged, where that time my uncle - Győző Bruckner - was a professor of chemistry at the University. Nevertheless, everybody could speak there German, consequently there was no need for me to learn the Hungarian language.

Whenever I visited my uncle at the university, I spent the most time in the workshop of the German speaking glass technician Mr Schlott, where I had the opportunity to learn the fundamental knowledge of this profession. I was fascinated by this glass-blowing technique and decided that time to become a chemist!

After absolving my secondary school in Miskolc in 1952, I enrolled the chemistry faculty of the Technical University of Budapest and graduated as a chemical engineer in 1957. Thereafter I joined the staff of the Institute for Drug Research in Budapest, where I was

a co-worker of professor Laszlo Vargha, who was the director of the institute. He had been an excellent carbohydrate chemist and successfully introduced carbohydrates as carriers for cytostatically active compounds, developing so the anticancer drug Degranol, which was successfully used for the treatment of leukaemia. When I entered his group, an extensive research was continued in this field, synthesising similar compounds, which as biological alkylating agents could be used for the treatment of cancer. This way I got familiar with carbohydrate chemistry and very much interested both, in stereochemistry as well as in reaction mechanisms, most of which are strongly related to the former one. During my research work I had of course to deal with different type of compounds looking for new potential drug candidates, but whenever possible I used carbohydrates as carriers for the biologically active groups. This way I became an expert in carbohydrate chemistry and was elected as the secretary for the carbohydrate section of the Hungarian Academy of sciences and held this position over a period of 22 years. Meanwhile I was the representative of Hungary in the European Carbohydrate Committee.

Beside my activity as a researcher, I defended my academical doctoral thesis in 1971. Later I was asked by both, the Technical University of Budapest and the Kossuth Lajos University of Debrecen to held regularly special courses on carbohydrate chemistry and habilitated at the latter university in 1994. I got a few decorations from the Ministry of Heavy Industry (where our institute belonged to) as well as from the Hungarian Academy of sciences, the latest one the Eötvös Laureat in 2014. 